\title{
The reality of Field's epistemological challenge to platonism
}

DOI:

10.1007/s10670-017-9925-z

\section{Document Version}

Accepted author manuscript

Link to publication record in Manchester Research Explorer

\section{Citation for published version (APA):}

Liggins, D. (2018). The reality of Field's epistemological challenge to platonism. Erkenntnis, 83, 1027-1031. https://doi.org/10.1007/s10670-017-9925-z

\section{Published in:}

Erkenntnis

\section{Citing this paper}

Please note that where the full-text provided on Manchester Research Explorer is the Author Accepted Manuscript or Proof version this may differ from the final Published version. If citing, it is advised that you check and use the publisher's definitive version.

\section{General rights}

Copyright and moral rights for the publications made accessible in the Research Explorer are retained by the authors and/or other copyright owners and it is a condition of accessing publications that users recognise and abide by the legal requirements associated with these rights.

\section{Takedown policy}

If you believe that this document breaches copyright please refer to the University of Manchester's Takedown Procedures [http://man.ac.uk/04Y6Bo] or contact uml.scholarlycommunications@manchester.ac.uk providing relevant details, so we can investigate your claim.

\section{OPEN ACCESS}


The reality of Field's epistemological challenge to platonism

Platonism in the philosophy of mathematics is the view that there are mathematical objects (such as numbers and sets) which are mind- and language- independent and neither spatiotemporally located nor causally active. Of the many philosophers who have suggested that platonism is epistemologically problematic, one of the most famous is Paul Benacerraf. In his 1973, Benacerraf tabled (but did not go so far as to endorse) an epistemological argument against platonism, based on the then-prominent causal theory of knowledge. That theory of knowledge has received much criticism, which is why few if any philosophers now endorse Benacerraf's argument. In the introduction to his 1989, and in earlier papers included in that collection, Hartry Field offered an epistemological challenge to platonism, which can be seen as a refinement of Benacerraf's. Justin Clarke-Doane (forthcoming 2016) argues that Field's challenge is an illusion: it does not pose a genuine problem for platonism. My aim is to show that Clarke-Doane's argument relies on a misunderstanding of Field's challenge. I begin by setting out Field's challenge, as I read it; I then explain how the argument Clarke-Doane discusses differs from Field's, and show that Field's actual argument is immune from ClarkeDoane's criticisms.

Field (1989: 25-30, 68, 230-9) points out that platonists must accept that the mathematical beliefs of mathematicians are largely true. Call this phenomenon 'MMA', for 'mathematicians' mathematical accuracy'. According to Field, MMA 'is so striking as to demand explanation' (1989: 26). How might platonists go about explaining it? Since the mathematical objects which, on their view, form the subject-matter of mathematical beliefs are not causally active, there 
cannot be a causal explanation. But it is hard see how a platonist could give a non-causal explanation of MMA. What would such an explanation look like? The challenge to platonists, then, is to provide an explanation of MMA.

Why does the correlation need to be explained? Field answers this question by way of an analogy:

It is rather as if someone claimed that his or her belief states about the daily happenings in a remote village in Nepal were nearly all disquotationally true, despite the absence of any mechanism to explain the correlation between those belief states and the happenings in the village. Surely we should accept this only as a very last resort. (1989: 26-7)

To sum up: Field's challenge to platonism is that it seems impossible for any platonist theory to explain MMA. As Field puts it:

Recall that on the usual platonist picture, mathematical objects are supposed to be mindand language- independent; they are supposed to bear no spatio-temporal relations to anything, etc. The problem is that the claims that the platonist makes about mathematical objects appear to rule out any reasonable strategy for explaining the systematic correlation in question. (Field 1989: 231)

Field takes it that this casts doubt on platonism (1989: 231). It is worth noting that there is no mention of justification here: according to Field, inability to explain MMA is an embarrassment 
for platonism because MMA is the sort of phenomenon which demands explanation (see REFERENCE REMOVED).

Clarke-Doane presents Field's work very differently. On his reading, Field's argument can be summarized as follows:

(1) It seems impossible for us to explain the reliability of our mathematical beliefs (such as our belief that $2+3=5$ ).

(2) If it seems impossible for us to explain the reliability of our mathematical beliefs, then they are not epistemically justified.

(3) Therefore, our mathematical beliefs are not epistemically justified.

(Clarke-Doane states Field's argument in this fashion in the last paragraph of section 2, the first paragraph of section 6, and the first paragraph of section 8 of his paper.)

Clarke-Doane goes on to argue that there is no sense of 'explain the reliability' in which (2) and (3) both hold. He maintains that for any sense of 'explain the reliability', either our reliability is explicable, or our inability to explain it does not imply that our mathematical beliefs are unjustified (see sections 3 to 6 of his paper). Clarke-Doane therefore concludes that Field's challenge is an illusion.

I have no quarrel to make with Clarke-Doane's discussion of this argument. My point is that the argument he discusses is not that of Field 1989. Here are two important differences between the arguments. 
First, Field's argument is a contribution to the debate between platonists and their opponents: specifically, it is an argument against platonism. His intention is to lower philosophers' confidence in a philosophical theory. On the other hand, Clarke-Doane portrays Field as arguing that our mathematical beliefs (such as the belief that $2+3=5$ ) are unjustified. He even remarks that Field did not seem to realize that his argument 'does not obviously depend on the view that mathematics has a peculiar ontology ... Abstract objects are not what give rise to the Benacerraf Problem in the first place' (Clarke-Doane forthcoming 2016 section 2). According to Clarke-Doane, there are parallel problems concerning morality, modality, and logic; and none of these areas of discourse 'has a peculiar ontology' (Clarke-Doane forthcoming 2016 section 2). Clarke-Doane sees these problems as raised by ideology ('is prime', 'is good', etc.) rather than by ontology.

Why think that Field's argument is an argument against platonism? The text is clear:

Perhaps the most widely discussed challenge to the platonist position is epistemological. ... Benacerraf's formulation of the challenge relied on a causal theory of knowledge which almost no one believes anymore; but I think that he was on to a much deeper difficulty with platonism..... Benacerraf's challenge - or at least, the challenge which his paper suggests to me-is to provide an account of the mechanisms that explain how our beliefs about those remote entities can so well reflect the facts about them. The idea is that if it appears in principle impossible to explain this, then that tends to undermine the belief in mathematical entities, despite whatever reason we might have for believing in them. (Field 1989: 25-6, italics in original) 
This passage leaves me in no doubt that belief in the existence of mathematical objects, as conceived by the platonist, is the intended target of the argument. Moreover, its context Field's longstanding campaign against platonism in the philosophy of mathematics - provides further confirmation of Field's intentions.

It might be suggested that the argument generalizes to the other domains which ClarkeDoane mentions - morality, modality, and logic - and that Field and other commentators have failed to spot this. But the suggestion has little plausibility. Part of the argument Field offers is that the platonist's claims about the nature of mathematical objects make it hard to see how a platonist could explain MMA. Field (1989: 232) explicitly contrasts his challenge with a similar challenge to explain why a person's beliefs about the electromagnetic field are accurate: in this case, Field claims, we can give a causal explanation of their accuracy, albeit somewhat sketchy, and so the challenge can be met. I see no reason to doubt what Field says about this case. It therefore seems that the platonist's claims about the nature of the mathematical objects they posit are an essential ingredient of the puzzle. (This means that Field's challenge generalizes, not to other domains, but to some philosophical accounts of other domains, specifically, those accounts which make it hard to explain the accuracy of our beliefs. The theory that our moral beliefs are largely true and concern moral values, conceived of as abstract objects, would thus be subject to a version of the challenge.)

A second difference is that Field's argument does not invoke the concept of justification, whereas on Clarke-Doane's reading the argument centrally involves this concept. Field is explicit that his challenge does not concern justification: 
The way to understand Benacerraf's challenge, I think, is not as a challenge to our ability to justify our mathematical beliefs, but as a challenge to our ability to explain the reliability of those beliefs. (Field 1989: 25)

Admittedly, Field's argument does concern justification in the sense that it aims to justify its conclusion, and thereby cast doubt on its negation. This is what Field has in mind with his talk of 'undermining' platonism, quoted above. In this sense, every argument concerns justification. What I mean by saying that Field's argument does not concern justification is that the premises and conclusion of the argument can all be formulated without using the concept of justification. Perhaps Clarke-Doane might respond by saying that if philosophers' belief in platonism is undermined, then so are the mathematical beliefs of people in general. We can set aside the matter of how plausible we should find this conditional, because proponents of Field's argument can happily concede it. Perhaps platonists' inability to explain the reliability of our people's mathematical beliefs does indeed undercut what justification those beliefs might otherwise have (testimonial justification, for instance). The point is that even if Field's claims have consequences for the epistemic standing of people's mathematical beliefs, that is not what his argument is meant to establish: rather, it is meant to cast doubt on a philosophical doctrine, namely, platonism.

Whilst I acknowledge that the argument which Clarke-Doane criticizes echoes some more recent statements of Field's (which Clarke-Doane cites), I take myself have shown that it differs from Field's 1989 argument in two significant ways. The import of these differences is clear. As I 
have explained, Clarke-Doane argues that there is no sense of 'explain the reliability' in which (1) and (2) both hold, and this is the basis of his negative verdict on Field's argument. Premiss (2) concerns the justification of our mathematical beliefs. But since Field's argument does not concern the justification of our mathematical beliefs, Clarke-Doane's objection does not touch it. (Moreover, since Clarke-Doane's objection revolves around the notion of justification, it is very hard to see how it could be adapted to apply to Field's argument.) So whatever else the significance of Clarke-Doane's argument may be, it should give no comfort to platonists.

Word count 1654

Acknowledgements

Thanks to Justin Clarke-Doane for discussion of an earlier draft; and [REMOVED].

Works cited

Benacerraf, Paul 1973. Mathematical truth. Journal of Philosophy 70: 661-79.

Clarke-Doane, Justin (forthcoming 2016). What is the Benacerraf problem? In Fabrice Pataut (ed.) New Perpectives on the Philosophy of Paul Benacerraf. Dordrecht: Springer. (Available at

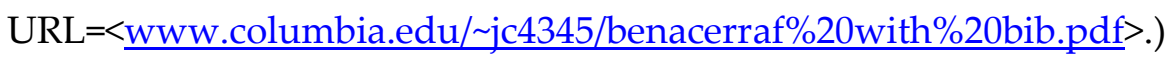

Field, Hartry 1989. Realism, Mathematics and Modality. Oxford: Blackwell.

Abstract. In the introduction to his Realism, Mathematics, and Modality (1989), and in earlier papers included in that collection, Hartry Field offered an epistemological challenge to 
platonism in the philosophy of mathematics. Justin Clarke-Doane (forthcoming 2016) argues that Field's challenge is an illusion: it does not pose a genuine problem for platonism. My aim is to show that Clarke-Doane's argument relies on a misunderstanding of Field's challenge. 